\title{
Paleogeograficzne uwarunkowania odpływu wód z zastoiska warszawskiego doliną Bachorzy i pradoliną warszawsko-berlińską w czasie stadiału głównego zlodowacenia wisły
}

\author{
Paleogeographical conditions of the outflow from the Warsaw ice-dammed lake through \\ the Bachorza valley and the Warsaw-Berlin pradolina during the Main Stage \\ of the Weichselian Glaciation
}

\author{
Paweł Molewski \\ Katedra Geomorfologii i Paleogeografii Czwartorzędu, Uniwersytet Mikołaja Kopernika, Toruń, molewski@umk.pl
}

\begin{abstract}
Zarys treści: Autor przedstawia nową koncepcję odpływu wód z zastoiska, które utworzyło się w Kotlinie Warszawskiej podczas stadiału głównego ostatniego zlodowacenia. Podstawową, dyskutowaną kwestią jest możliwość odpływu tych wód pradoliną warszawsko-berlińską, w świetle współczesnych stosunków hipsometrycznych w jej wschodnim odcinku. Opracowany nowy schemat zasięgów lądolodu stadiału głównego zlodowacenia wisły umożliwia w starszej fazie tego stadiału (fazie leszczyńskiej) odpływ wód z zastoiska z pominięciem jej wschodniego odcinka przez dolinę Bachorzy. Autor rozważa również rolę halokinezy w zmianie stosunków hipsometrycznych we wschodniej części pradoliny warszawsko-berlińskiej.
\end{abstract}

Słowa kluczowe: dolina marginalna Bachorzy, pradolina warszawsko-berlińska, zastoisko warszawskie, zlodowacenie wisły

\begin{abstract}
The author presents a new concept of the outflow from the ice-dammed lake that formed in the Warsaw Basin during the Main Stage of the last glaciation. The basic issue under discussion is the possibility of the outflow along the Warsaw-Berlin pradolina in the light of the contemporary hypsometric relations in its eastern section. A new scheme of the ice sheet ranges during the Main Stage of the Weichselian Glaciation reveals that during the older phase of this stage, the Leszno Phase, the outflow from the ice-dammed lake was possible through the Bachorza valley, i.e. omitting the Ice-marginal Valley's eastern section. The author also considers the role of halokinesis in changing the hypsometrical conditions in the eastern part of the Warsaw-Berlin pradolina.
\end{abstract}

Key words: Bachorza ice-marginal valley, Warsaw-Berlin pradolina, Warsaw ice-dammed lake, Weichselian Glaciation

\section{Wstęp}

Pradoliny subsekwentne i doliny marginalne odegrały podstawową rolę w odpływie wód na Niżu Środkowoeuropejskim w czasie zlodowacenia wisły. $\mathrm{O}$ ile te pierwsze, jak powszechnie znana pradolina warszawsko-berlińska, miały walny, ponadregionalny charakter, o tyle dolinom marginalnym przypisuje się na ogół znaczenie regionalne/lokalne. $\mathrm{W}$ świetle najnowszych koncepcji dolina marginalna Bachorzy jawi się jako jeden z kluczowych, ponadregionalnych elementów odpływu wód ekstra- i proglacjalnych w czasie maksimum ostatniego zlodowacenia (por. Molewski 2012b).
Dolina Bachorzy jest największą doliną marginalną Wysoczyzny Kujawskiej. Położona jest w południowej części mezoregionu Równiny Inowrocławskiej (Kondracki 1998). Przebiega od okolic Brześcia Kujawskiego na wschodzie po okolice Kruszwicy na zachodzie, gdzie łączy się z rynną Gopła i doliną Noteci (ryc. 1). O jej genezie i roli $\mathrm{w}$ odpływie wód $\mathrm{w}$ okresie recesji ostatniego lądolodu wypowiadało się wielu badaczy już od pierwszej połowy XX w. (Lencewicz 1927, Galon 1929, Wiśniewski 1974, 2003, 2005, Niewiarowski 1983a, b, Molewski 1999, 2007).

Długość doliny wynosi $41,5 \mathrm{~km}$, a jej szerokość jest zmienna: od 0,6-1,0 km w części wschodniej, 1,5-2,0 km 


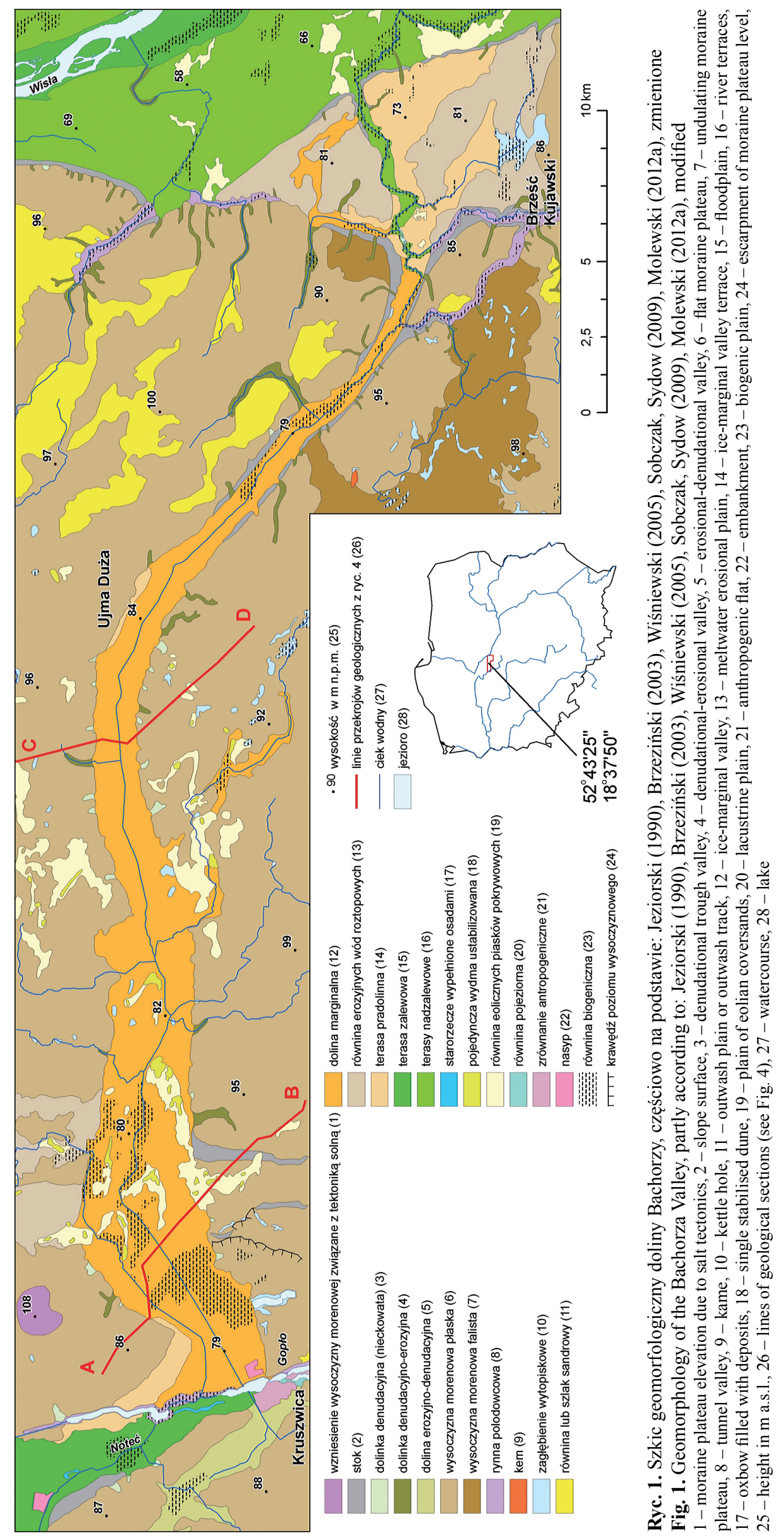


w części środkowej, do 4,0 km w części zachodniej (ryc. 1). Szczególnymi cechami morfologii doliny są wypukły profil jej dna, duża szerokość i regularny, łukowaty przebieg. Dno doliny Bachorzy leży na wysokości 79-80 m n.p.m. w rejonie Brześcia Kujawskiego i wznosi się do 84 m n.p.m. w okolicy wsi Ujma Duża, w pobliżu której przebiega dział wodny pomiędzy dorzeczami Wisły i Odry. Dalej, w kierunku zachodnim, dno doliny obniża się do wysokości 80 m n.p.m. w rejonie Kruszwicy. Wypiętrzenie dna doliny Bachorzy wynosi więc 4-5 m. Według Wiśniewskiego (1974, 1976, 1990) przyczyną wyniesienia dna doliny były ruchy skorupy ziemskiej - neotektoniczne lub glacjoizostatyczne. Zdaniem Niewiarowskiego (1983a) i Molewskiego (2007) należy je wiązać z tektoniką solną. Ponadto według autora z tektoniką tą należy również łączyć charakterystyczny łukowaty kształt tej doliny (Molewski 2007). Badania osadów w dnie doliny wykazały, że w czasie recesji ostatniego lądolodu wody przepływały w niej w kierunku zachodnim (Wiśniewski 1974).

Jednym z istotnych problemów paleogeograficznych zlodowacenia wisły, ściśle wiążącym się z pradoliną warszawsko-berlińską i doliną Bachorzy, jest ich rola w odpływie wód z powstałego w czasie ostatniego zlodowacenia w Kotlinie Warszawskiej jeziora proglacjalnego, tzw. zastoiska warszawskiego. Dotychczasowe koncepcje dotyczące tego zagadnienia, w kontekście szerszych badań zastoiska, zostały podsumowane przez Wiśniewskiego (2003, 2005).

\section{Problem odpływu wód z zastoiska warszawskiego}

Podstawową, nierozstrzygniętą kwestią jest możliwość odpływu wód $\mathrm{z}$ zastoiska warszawskiego pradoliną warszawsko-berlińską. Zdaniem Wiśniewskiego (2003, 2005) w świetle analizy współczesnych stosunków hipsometrycznych wschodniego odcinka pradoliny nie było to możliwe. Dno pradoliny na dziale wodnym Wisły i Odry pod Łęczycą, kilkadziesiąt kilometrów na zachód od Kotliny Warszawskiej, położone jest na wysokości około 102 m n.p.m. Wartość ta koreluje z maksymalną wysokością zalegania osadów zastoiska warszawskiego (Baraniecka, Konecka-Betley 1987). Przyjmując odpowiednio wyższy poziom wód zastoiska odpływ przez współczesny dział wodny pod Łęczycą, można uznać za możliwy. Jednocześnie wysokość ta znacznie przewyższa suponowany maksymalny poziom zastoiska warszawskiego, tj. około 84 m n.p.m., określony na podstawie badań geomorfologicznych dolin proglacjalnych uchodzących do pradoliny na zachód od Kotliny Warszawskiej (Wiśniewski, Andrzejewski 1994). Konsekwencją takiego założenia jest pytanie stawiane przez Wiśniewskiego (2003, 2005: 133), czy zastoisko „mogło istnieć przez ponad 2 tys. lat”?, tj. między maksymalnym zasięgiem lądolodu zlodowacenia wisły w fazie leszczyńskiej a subfazą kujawsko-do- brzyńską (przebiegającą w północnej części Wysoczyzny Kujawskiej i Dobrzyńskiej), bez możliwości odpływu (istnienia „kanału ulgi”), stale zasilane przez wody ekstraglacjalne i proglacjalne. Cytowany autor dopuszcza możliwość, że dno pradoliny warszawsko-berlińskiej w okolicy Łęczycy leżało w czasie maksimum zasięgu ostatniego lądolodu niżej niż współcześnie. Jego obecna wysokość teoretycznie może być efektem wznoszących ruchów neotektonicznych, glaciizostatycznych lub halokinetycznych, na które jednak nie ma jednoznacznych dowodów (Wiśniewski 2003, 2005). Zdaniem Mojskiego (2005: 252) możliwość zaznaczenia się wznoszących ruchów skorupy ziemskiej w rozpatrywanym odcinku pradoliny jest bardzo prawdopodobna. Autor ten wiąże je z przecinającym pradolinę wałem kujawsko-pomorskim, którego mobilność w czwartorzędzie została udowodniona w wielu miejscach. Wielkość wznoszących ruchów pionowych dla analizowanego odcinka pradoliny szacuje na około $20 \mathrm{~m}$ od początku jej funkcjonowania.

Zakładając brak możliwości odpływu wód z zastoiska pradoliną warszawsko-berlińską Wiśniewski (2003, 2005) sformułował kontrowersyjną hipotezę, że wody te odpływały pod lądolodem (ryc. 2). Płynęły one na obszarze Kotliny Płockiej, a następnie na zachód w warunkach subglacjalnych na linii doliny marginalnej Bachorzy lub rynny Zgłowiączki i doliny głuszyńskiej do rynny Gopła. Dalej wody te odpływały na południe rynną Gopła i Jeziora Ślesińskiego do pradoliny w okolicach Konina, na wschód od działu wodnego pod Łęczycą. Wiśniewski (2003, 2005) sugeruje tym samym istnienie marginalnej rynny subglacjalnej na dalekim zapleczu czoła lądolodu (30-50 km), której przebieg reprodukuje dolina Bachorzy.

Nie wnikając w dalsze szczegóły rozpatrywanego problemu, w tym przede wszystkim w kontrowersje co do maksymalnego poziomu wód zastoiska, autor chciałby przedstawić jego nowe aspekty w świetle nowszych badań (Molewski 2007, Wysota i in. 2009, Wysota, Molewski 2011). Dotyczyć one będą zdarzeń paleogeograficznych związanych $z$ nasunięciem i maksymalnym zasięgiem lądolodu na obszarze lobu Wisły podczas stadiału głównego ostatniego zlodowacenia.

\section{Odpływ z zastoiska warszawskiego doliną marginalną Bachorzy w świetle nowych badań}

Jedną z kluczowych kwestii, w kontekście istnienia „kanału ulgi" z zastoiska warszawskiego, jest okres funkcjonowania zastoiska w czasie maksimum zasięgu lądolodu zlodowacenia wisły. Wiąże się ona z odmiennymi poglądami co do liczby, zasięgu i wieku (leszczyński albo poznański) nasunięć ostatniego lądolodu na obszarze tzw. lobu Wisły (por. Wysota, Molewski 2007), którego osią morfologiczną jest dolina Wisły.

Badania geologiczne autora (Molewski 2007) na obszarze Wysoczyzny Kujawskiej, zajmującej zasadniczą 


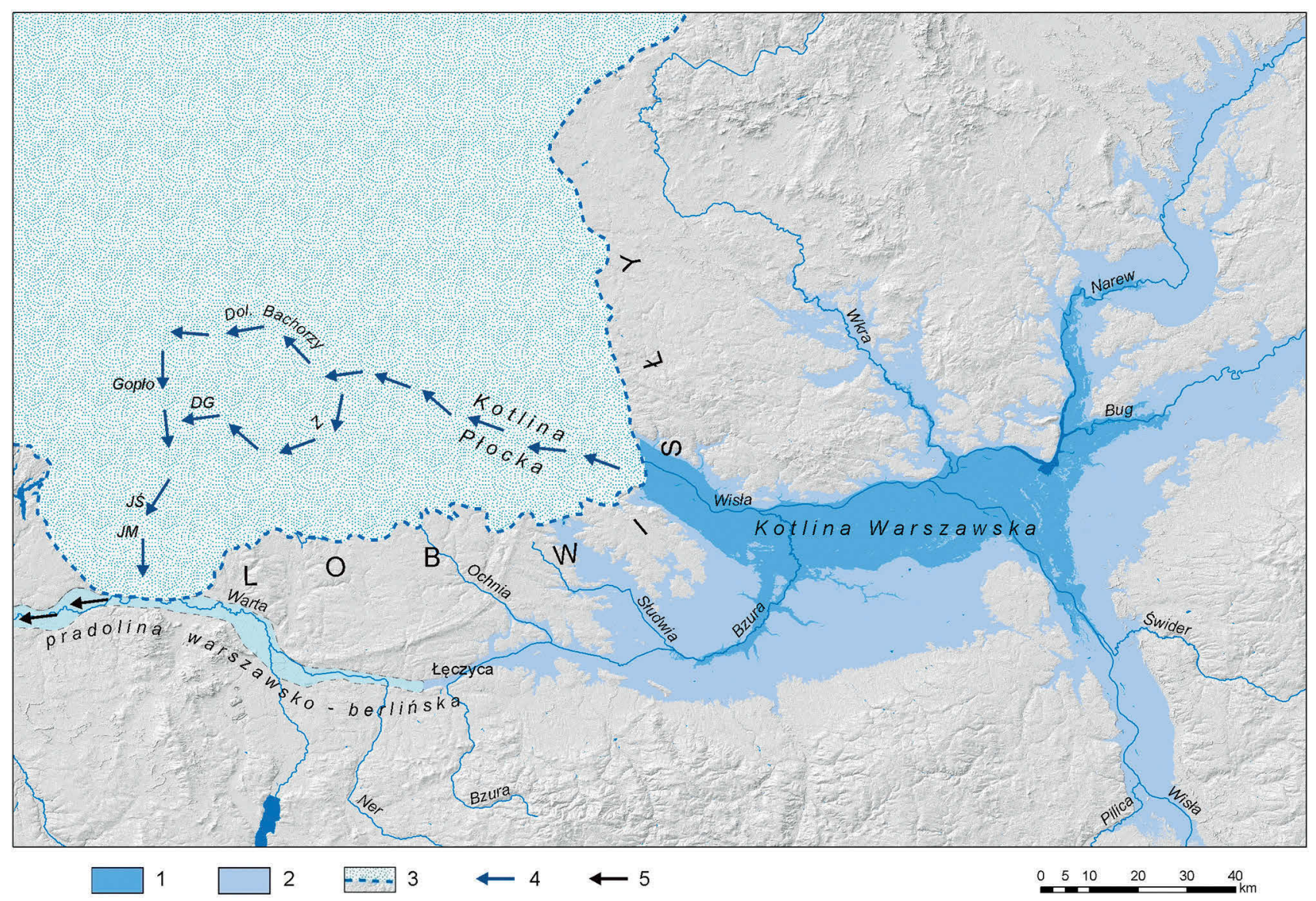

Ryc. 2. Prawdopodobne drogi odpływu wód z zastoiska warszawskiego według Wiśniewskiego (2003, 2005)

1 - zasięg zastoiska w poziomie $84 \mathrm{~m}$ n.p.m. na tle współczesnej hipsometrii i rzeźby terenu, 2 - zasięg zastoiska w poziomie $102 \mathrm{~m} \mathrm{n.p.m.,} 3$ - zasięg lądolodu w fazie leszczyńskiej według części autorów, 4 - przepływ wód w warunkach subglacjalnych, 5 - przepływ wód w warunkach subaeralnych; objaśnienia skrótów: Z - Zgłowiączka, DG - dolina głuszyńska, JŚ - Jezioro Ślesińskie, JM - Jezioro Mikorzyńskie

Fig. 2. Possible outflow routes from the Warsaw ice-dammed lake according to Wiśniewski $(2003,2005)$

1 - range of the ice-dammed lake at the elevation $84 \mathrm{~m}$ a.s.l. against the modern-day hypsometry and relief, 2 -range of the ice-dammed lake at the 102 $\mathrm{m}$ a.s.l., 3 - range of the ice sheet in the Leszno Phase according to some authors, 4 - water course in the subglacial conditions, 5 - water course in the subaeral conditions; abbreviations: Z - Zgłowiączka, DG - Głuszyńska Valley, JŚ - Ślesińskie Lake, JM - Mikorzyńskie Lake

część lobu Wisły, wykazały brak dowodów na odrębność litostratygraficzną fazy leszczyńskiej i poznańskiej na analizowanym terenie. Dały one asumpt do postawienia hipotezy, że zasięg lądolodu fazy leszczyńskiej był w lobie Wisły znacznie mniejszy niż fazy poznańskiej. Badania tego zagadnienia w obrębie całego lobu zweryfikowały tę hipotezę i potwierdziły jej podstawowe założenie (Wysota $\mathrm{i}$ in. 2009, Wysota, Molewski 2011). Opracowano nowy schemat nasunięć ostatniego lądolodu w zasięgu lobu Wisły podczas stadiału głównego ostatniego zlodowacenia. Oparty był on na szczegółowych badaniach litofacjalnych osadów i cech kierunkowych depozycji glin morenowych w kilkudziesięciu odsłonięciach w zestawieniu z wynikami wcześniejszych prac innych autorów. Podstawowymi kryteriami końcowych wniosków stratygraficznych była liczba wyróżnionych pokładów glin morenowych i liczne datowania wieku osadów piaszczystych uzyskane metodami luminescencyjnymi.

W opracowanym schemacie obszar Kotliny Płockiej, Wysoczyzny Kujawskiej i Dobrzyńskiej przykryty został przez lądolód stadiału głównego zlodowacenia wisły tylko w jego młodszej, maksymalnej fazie, tj. poznańskiej (ryc. 3). Podczas fazy leszczyńskiej czoło lądolodu zatrzymało się około 20500 lat BP w skrajnie północnej części wymienionych wysoczyzn (Wysota i in. 2009, Wysota, Molewski 2011). W efekcie tamowane wody ekstrai proglacjalne mogły odpływać $\mathrm{w}$ warunkach subaeralnych istniejącymi wówczas dolinami (Molewski 1999, 2007), przebiegającymi na linii współczesnej doliny marginalnej Bachorzy oraz rynien subglacjalnych Gopła oraz Jezior Ślesińskiego i Mikorzyńskiego do pradoliny z pominięciem jej wschodniego odcinka.

$\mathrm{O}$ istnieniu kopalnej doliny marginalnej sprzed nasunięcia ostatniego lądolodu na obszar Wysoczyzny Kujawskiej, do której nawiązuje przebieg współczesnej doliny Bachorzy, świadczą przekroje geologiczne wykonane przez tę dolinę (ryc. 4). Osady wodnolodowcowe kopalnej doliny marginalnej z fazy leszczyńskiej zlodowacenia wisły rozcinają gliny zwałowe zaliczone do zlodowacenia warty, a w części zachodniej doliny również interglacjału eemskiego. Ich miąższość wynosi od kilku do $15 \mathrm{~m}$, a strop zalega na wysokości od 70 do $85 \mathrm{~m}$ n.p.m. Ponad nimi występuje jeden pokład gliny zwałowej zaliczonej do fazy poznańskiej ostatniego zlodowacenia. Osady 


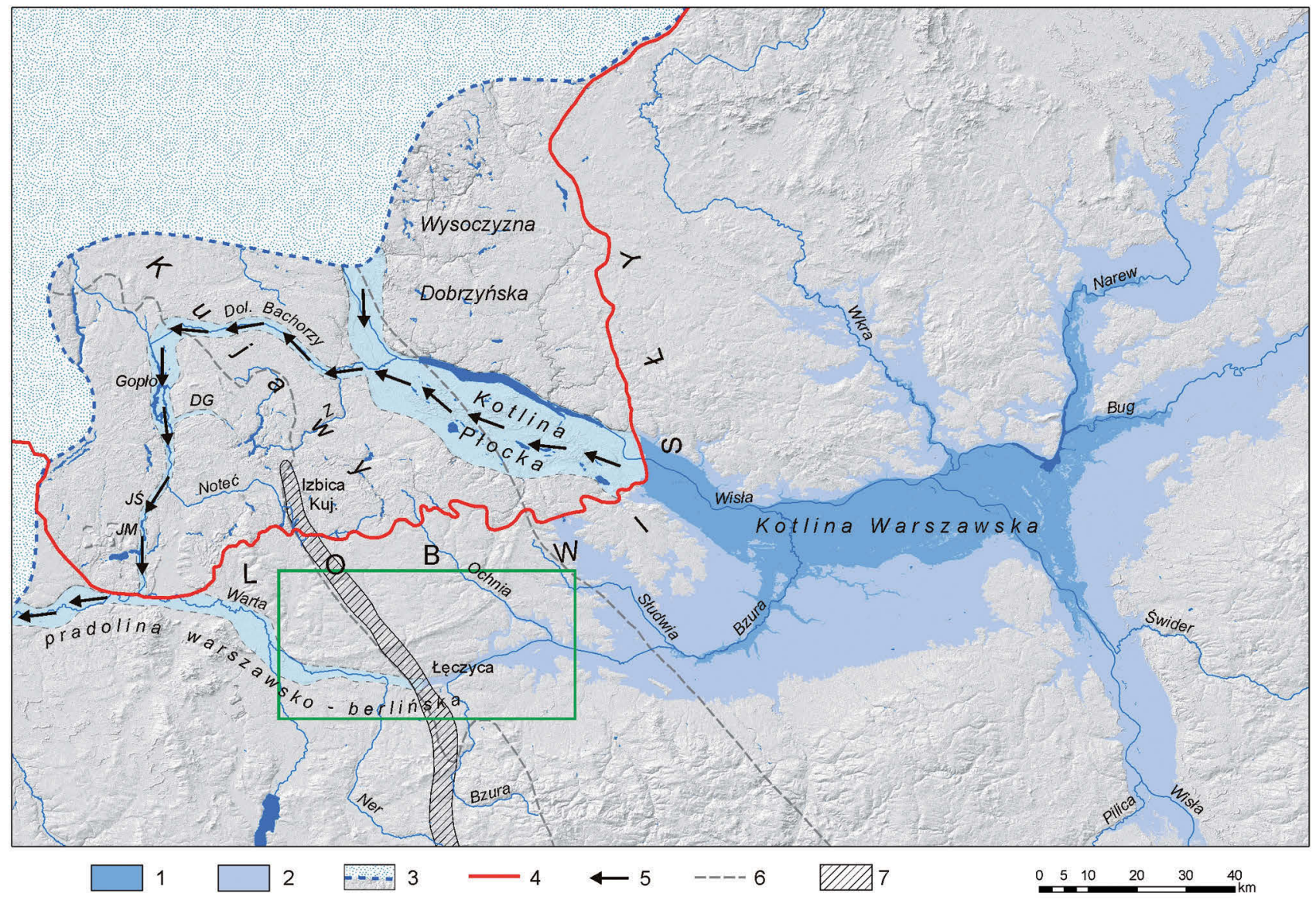

Ryc. 3. Odpływ wód z zastoiska warszawskiego według autora w czasie fazy leszczyńskiej zlodowacenia wisły; w zielonej ramce obszar przedstawiony na rycinie 6

1 - zasięg zastoiska w poziomie 84 m n.p.m. na tle współczesnej hipsometrii i rzeźby terenu, 2 - zasięg zastoiska w poziomie $102 \mathrm{~m}$ n.p.m., 3 - zakładany zasięg lądolodu w fazie leszczyńskiej (za Wysota, Molewski 2011), 4 - zasięg fazy poznańskiej (fazy leszczyńskiej wg części autorów), 5 - zakładany przepływ wód z zastoiska warszawskiego, 6 - granice wału kujawskiego (za Dadlez i in., 1998), 7 - przebieg antykliny solnej Izbica-Łęczyca (za Dadlez i in. 1998); objaśnienia skrótów: Z - Zgłowiączka, DG - dolina głuszyńska, JŚ - Jezioro Ślesińskie, JM - Jezioro Mikorzyńskie

Fig. 3. Outflow from the Warsaw ice-dammed lake according to the author during the Leszno Phase of the Weichselian Glaciation; the green frame shows the area presented in Figure 6

1 - range of the ice-dammed lake at the elevation of $84 \mathrm{~m}$ a.s.l. against the modern-day hypsometry and relief, 2 - range of the ice-dammed lake at the elevation of $102 \mathrm{~m}$ a.s.1., 3 - assumed range of the ice sheet in the Leszno Phase (after Wysota, Molewski 2011), 4 - range of the Poznan Phase (the Leszno Phase by some authors), 5 - assumed water course from the Warsaw ice-dammed lake, 6 - boundaries of the Kujawy Swell (after Dadlez et al. 1998), 7 - course of the Izbica-Łęczyca salt anticline (after Dadlez et al. 1998); abbreviations: Z - Zgłowiączka, DG - Głuszyńska Valley, JŚ - Ślesińskie Lake, JM - Mikorzyńskie Lake

wodnolodowcowe $\mathrm{z}$ recesji lądolodu tej fazy w dolinie Bachorzy osiągają miąższość około $10 \mathrm{~m}$. Zalegają na glinie fazy poznańskiej lub rozcinają tę glinę oraz starsze osady wodnolodowcowe z fazy leszczyńskiej i gliny zlodowacenia warty.

Tak więc po recesji z fazy leszczyńskiej nastąpiło ponowne nasunięcie lądolodu w fazie poznańskiej, które przekroczyło zasięg starszej fazy zlodowacenia i osiągnęło maksimum w lobie Wisły około 18500 lat BP (Wysota $\mathrm{i}$ in. 2009, Wysota, Molewski 2011). Biorąc pod uwagę zakładane tempo nasunięcia i recesji lądolodu w tej fazie zlodowacenia oraz zakładaną możliwość odpływu wód z pominięciem wschodniego odcinka pradoliny zarówno w czasie nasunięcia lądolodu, jak i jego recesji, należy stwierdzić, że czas funkcjonowania zastoiska skróciłby się z zakładanych przez Wiśniewskiego (2003, 2005) 2000 lat do maksymalnie 300 lat.
Czy zatem skrócenie potencjalnego czasu istnienia zastoiska do kilkuset, a nawet kilkudziesięciu lat umożliwiałoby jego funkcjonowanie bez możliwości odpływu?

\section{Estymacja czasu wypełnienia wodami zastoiska warszawskiego}

Przeprowadzona przez autora estymacja czasu wypełnienia zastoiska warszawskiego w oparciu o bilans zmian jego objętości ma szereg istotnych ograniczeń (ryc. 5). Wynikają one głównie z przybliżeń objętości zastoiska i wielkości dopływu. Nie wiemy bowiem, jakie było pierwotne ukształtowanie zalanego terenu i kiedy, tj. w jakiej fazie transgresji ostatniego lądolodu, nastąpił początek formowania zastoiska. Ponadto istnieją kontrowersje co 

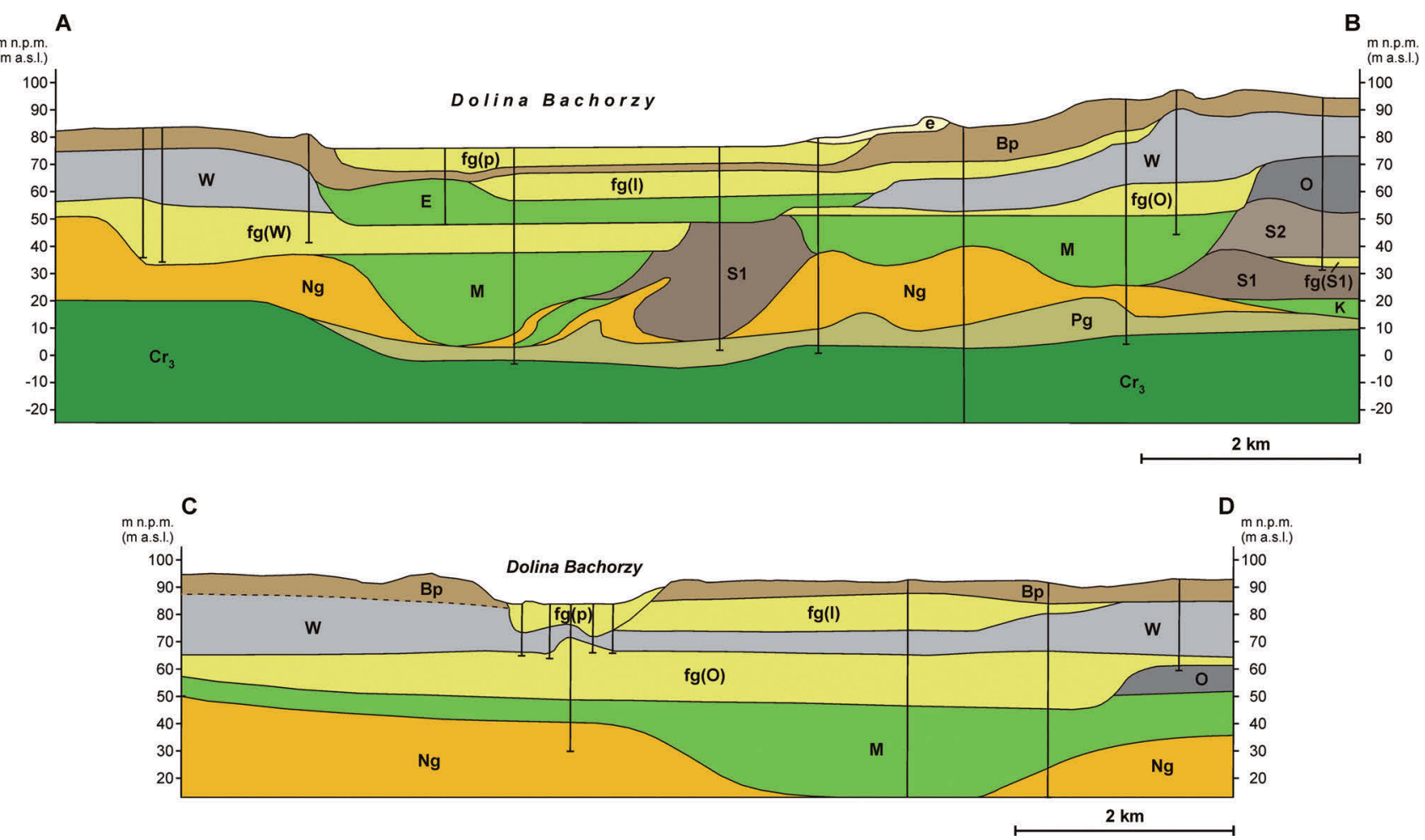

Ryc. 4. Przekroje geologiczne przez dolinę Bachorzy (przebieg linii przekrojów na ryc. 1), przekrój A-B na podstawie Molewskiego (2013)

$\mathrm{Cr}_{3}$ - skały kredy górnej, Pg - osady paleogenu, $\mathrm{Ng}$ - osady neogenu, S1- gliny zwałowe zlodowacenia sanu 1, S2 - gliny zwałowe zlodowacenia sanu $2, \mathrm{O}$ - gliny zwałowe zlodowacenia odry, $\mathrm{W}$ - gliny zwałowe zlodowacenia warty, $\mathrm{Bp}$ - gliny zwałowe fazy poznańskiej zlodowacenia wisły, $\mathrm{K}$ - osady rzeczne interglacjału małopolskiego, $\mathrm{M}$ - osady rzeczne interglacjału wielkiego, E - osady rzeczne interglacjału eemskiego, fg(S1) - osady wodnolodowcowe zlodowacenia sanu $1, \mathrm{fg}(\mathrm{O})$ - osady wodnolodowcowe zlodowacenia odry, $\mathrm{fg}(\mathrm{W})$ - osady wodnolodowcowe zlodowacenia warty, fg(l) - osady wodnolodowcowe fazy leszczyńskiej zlodowacenia wisły, $f g(p)$ - osady wodnolodowcowe fazy poznańskiej zlodowacenia wisły, e - osady eoliczne

Fig. 4. Geological cross-sections across the Bachorza Valley (the course of the cross-sections in Fig. 1), cross-section A-B after Molewski (2013)

$\mathrm{Cr}_{3}$ - deposits of the Upper Cretaceous, $\mathrm{Pg}$ - deposits of the Paleogene, $\mathrm{Ng}$ - deposits of the Neogene, $\mathrm{S} 1$ - tills of the San 1 Glaciation (Elsterian), S2 - tills of the San 2 Glaciation (Elsterian), O - tills of the Odra Glaciation (Saalian), W - tills of the Warta Glaciation (Saalian), Bp - tills of the Poznan Phase, the Weichselian Glaciation, $\mathrm{K}$ - fluvial sediments from the Małopolska Interglacial, M - fluvial sediments from the Great Interglacial (Holstein), E - fluvial sediments from the Eemian Interglacial, fg(S1) - glaciofluvial deposits of the San 1 Glaciation (Elsterian), fg(O) - glaciofluvial deposits of the Odra Glaciation (Saalian), $\mathrm{fg}(\mathrm{W})$ - glaciofluvial deposits of the Warta Glaciation (Saalian), $f g(l)$ - glaciofluvial deposits of the Leszno Phase, the Weichselian Glaciation, $f g(p)$ - glaciofluvial deposits of the Poznan Phase, the Weichselian Glaciation, e - aeolian deposits

do maksymalnego poziomu jego wód. Nie znamy również wielkości dopływu wód do zastoiska, a ponadto wielkości parowania z jego powierzchni oraz filtracji wód do podłoża. W estymacji przyjęto dwa różne, suponowane w literaturze, poziomy wód zastoiska, tj. 102 i $84 \mathrm{~m}$ n.p.m. Ich konsekwencją są dwie różne objętości zastoiska obliczone na podstawie cyfrowego modelu wysokościowego. Jako wielkość dopływu wód do zastoiska przyjęto współczesne przepływy wód Wisły na odcinku warszawskim. Wielkość dopływu wód do zastoiska jest więc istotnie zaniżona, biorąc pod uwagę fakt, że nie uwzględniono w niej dopływu wód roztopowych i innych wód ekstraglacjalnych, poza wodami Wisły.

Nie wnikając we wszystkie nieokreślone i hipotetyczne zmienne bilansu pracy zastoiska, należy stwierdzić, że przeprowadzona estymacja jego wypełnienia wodami ekstra- i proglacjalnymi sugeruje, że jego tempo było bardzo szybkie (ryc. 5). Czas wypełnienia zbiornika do zakładanych wysokości nie przekroczył kilku lat, a być może miesięcy. Szacunki te wskazują, że mimo znacznego skrócenia czasu tamowania wód zastoiska przez lą- dolód, musiał istnieć z niego odpływ przed ponownym udrożnieniem przepływu m.in. przez reprodukowaną dolinę marginalną Bachorzy.

\section{Neotektoniczne uwarunkowania możliwości odpływu wód z zastoiska warszawskiego pradoliną warszawsko-berlińską}

Zatem aktualne pozostają pytania: czy odpływ wód z zastoiska mógł się odbywać przez pradolinę warszawsko-berlińską w poziomie powyżej $102 \mathrm{~m}$ n.p.m.? i czy współczesny dział wodny Wisły i Odry pod Łęczycą to efekt postglacjalnych ruchów pionowych skorupy ziemskiej?

Zagadnienie prawdopodobnych ruchów pionowych skorupy ziemskiej we wschodnim odcinku pradoliny warszawsko-berlińskiej było jak dotąd podejmowane w sposób ogólny (m.in. Jewtuchowicz 1967, Mojski 2005). Kluczową strukturą geologiczną dla rozstrzygnięcia tego problemu jest zdaniem autora antyklina solna Izbica-Łę- 


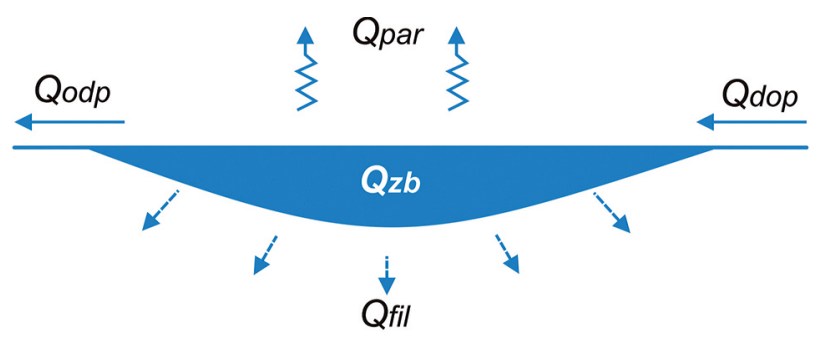

Składowe bilansu pracy zastoiska:

Qdop $=$ dopływ do zastoiska $\left[\mathrm{m}^{3} / \mathrm{s}\right]$

Qodp = odpływ z zastoiska $\left[\mathrm{m}^{3} / \mathrm{s}\right]$

Qpar = parowanie z powierzchni zastoiska $\left[\mathrm{m}^{3} / \mathrm{s}\right]$

Qfil = filtracja do podłoża $\left[\mathrm{m}^{3} / \mathrm{s}\right]$

Qzb = akumulacja wody w zastoisku [ $\left.\mathrm{m}^{3} / \mathrm{s}\right]$

Bilans zmian objętości zastoiska

$\frac{\Delta V}{\Delta t}=$ Qdop + Qzb - Qpar - Qfil - Qodp

$\Delta V$ - przyrost objętości zastoiska [m³]

$\Delta t$ - okres bilansowania (j.czasu)

Bilans przepływu przez zastoisko

$Q_{d o p}=Q_{o d p}+Q_{p a r}+Q_{f i l}+Q_{z b}$

Czas wypełnienia zastoiska przy braku odpływu

$$
\Delta t=\frac{V \max }{Q_{d o p}}\left[\frac{\mathrm{m}^{3}}{\mathrm{~m}^{3} / \mathrm{s}}\right]
$$

$V_{\text {max }}=$ maksymalna objętość zastoiska

Qdop $=$ Qpar(?) + Qfil(?) + Qzb

\begin{tabular}{|c|c|c|c|}
\hline $\begin{array}{l}\text { Poziom wód zasto- } \\
\text { iska w m n.p.m. } \\
\text { (Water level of the } \\
\text { ice-dammed lake } \\
\text { in } \mathrm{m} \text { a.s.l.) }\end{array}$ & $\begin{array}{c}\text { Objętość } \\
\text { zastoiska w } \mathrm{km}^{3} \\
(\text { Volume of the ice- } \\
\text { dammed lake in } \mathrm{km}^{3} \text { ) }\end{array}$ & $\begin{array}{l}\text { Dopływ wód } \\
\mathrm{w} \mathrm{m}^{3} / \mathrm{s} \\
\text { (Inflow of water } \\
\text { in } \mathrm{m}^{3} / \mathrm{s} \text { ) }\end{array}$ & $\begin{array}{l}\text { Czas wypełnie- } \\
\text { nia w miesiącach } \\
\text { (Time of filling } \\
\text { in months) }\end{array}$ \\
\hline 84 & 16,32 & $\begin{array}{r}561^{(1)} \\
5650^{(2)}\end{array}$ & $\begin{array}{r}11 \\
1\end{array}$ \\
\hline 102 & 88,97 & $\begin{array}{r}561^{(1)} \\
5650^{(2)}\end{array}$ & $\begin{array}{r}61 \\
6\end{array}$ \\
\hline
\end{tabular}

(1) średni przepływ Wisły na odcinku warszawskim (the average flow of the Vistula River in Warsaw)

(2) największa wartość przepływu Wisły w latach 1951-1997 (the largest flow of the Vistula River in the years 1951-1997)

Ryc. 5. Estymacja czasu wypełnienia zastoiska warszawskiego wodami ekstra- i proglacjalnymi

Fig. 5. Estimation of the time of filling up the Warsaw ice-dammed lake with the extra-glacial and pro-glacial water

czyca, o generalnym przebiegu NW-SE, położona przy południowo-zachodniej krawędzi wału kujawskiego (ryc. 3). Ze strukturą tą pokrywa się dział wodny pod Łęczycą, a o jej aktywności w górnym plejstocenie świadczą cechy morfologii i hydrografii rozpatrywanego obszaru. $\mathrm{Na}$ północ od działu wodnego, ponad antykliną solną, prostopadle do jej kierunku, przebiega tzw. kutnowska morena czołowa, położona na granicy Wysoczyzny Kłodawskiej i Równiny Kutnowskiej (Kondracki 1998). Kulminacja tej formy w okolicach wsi Sławoszew nawiązuje do przebiegu antykliny (ryc. 6A). Zakładane ruchy wypiętrzające, jeżeli wpłynęły na wysokość tej części moreny, powinny zaznaczyć się również na jej przedpolu i zapleczu. Wykonane profile podłużne przez rozpatrywaną część moreny kutnowskiej, wysoczyznę morenową na jej przedpolu i zapleczu oraz dno pradoliny warszawsko-berlińskiej pod Łęczycą potwierdzają tę hipotezę (ryc. 6B). Ponadto jednym ze wskaźników dźwigania się terenu jest nagła zmiana biegu rzek (m.in. Holbrook, Schumm 1999, Schumm $\mathrm{i}$ in. 2000). Zmiana taka charakteryzuje nie tylko Bzurę pod Łęczycą (stare koryto Bzury), ale również szereg innych cieków na analizowanym obszarze. Autor szacuje wielkość wznoszących ruchów pionowych w tej części moreny kutnowskiej, otaczających ją wysoczyzn i pradoliny warszawsko-berlińskiej pod Łęczycą na 10-15 m.

Aktywność antykliny solnej Izbica-Łęczyca od schyłku ostatniego zlodowacenia trudna jest jednak do dowiedzenia. Prawdopodobnie związana jest ona z obciążeniem i odciążeniem litosfery przez ostatni lądolód skandynawski. Zdaniem Wilkosza (2008) wzrost obciążenia, a następnie odprężenie powierzchni litosfery spowodowane cyklicznymi zjawiskami glacjacji i deglacjacji najprawdopodobniej nie miały większego znaczenia dla wzrostu aktywności wysadów solnych. Ich nieznacznie większą aktywność wiąże on jednak ze schyłkiem zlodowaceń i początkiem interglacjałów. Ponadto w analizowanym przypadku istotny jest fakt, że antyklina solna Izbica-Łęczyca była przykryta lądolodem zlodowacenia wisły tylko w północnej części.

Mimo powyższych zastrzeżeń, autor stawia hipotezę, że aktywność struktury solnej Izbica-Łęczyca nastąpiła od schyłku ostatniego zlodowacenia i podobnie jak struktur solnych na obszarze Wysoczyzny Kujawskiej (Molewski 2007) była wzbudzona jej wcześniejszym obciążeniem przez lądolód. Prawdopodobnie była ona uwarunkowana asymetrią tego obciążenia. W konsekwencji wypiętrzeniu uległ obszar pokrywający się z antykliną poza zasięgiem ostatniego lądolodu. Hipoteza ta nawiązuje w swej istocie do koncepcji ruchów soli inicjowanych obciążeniem progradujących osadów (m.in. Ge i in. 1997).

\section{Podsumowanie}

Analiza paleogeograficznych uwarunkowań odpływu wód z zastoiska warszawskiego w czasie stadiału głównego zlodowacenia wisły wskazuje na istotną rolę, jaką odegrała w nim dolina Bachorzy. Ponadto potwierdza ona wcześniejsze tezy o złożonej genezie tej formy (Molewski 1999, 2007). W świetle nowych poglądów co do liczby, zasięgu i wieku nasunięć ostatniego lądolodu na obszarze tzw. lobu Wisły (Wysota i in. 2009, Wysota, Molewski 2011) autor przyjął założenie, iż odpływ wód na linii współczesnej doliny Bachorzy miał miejsce dwukrotnie. W przedmaksymalnej fazie leszczyńskiej i w fazie recesji z maksymalnej fazy poznańskiej. Założenie to 


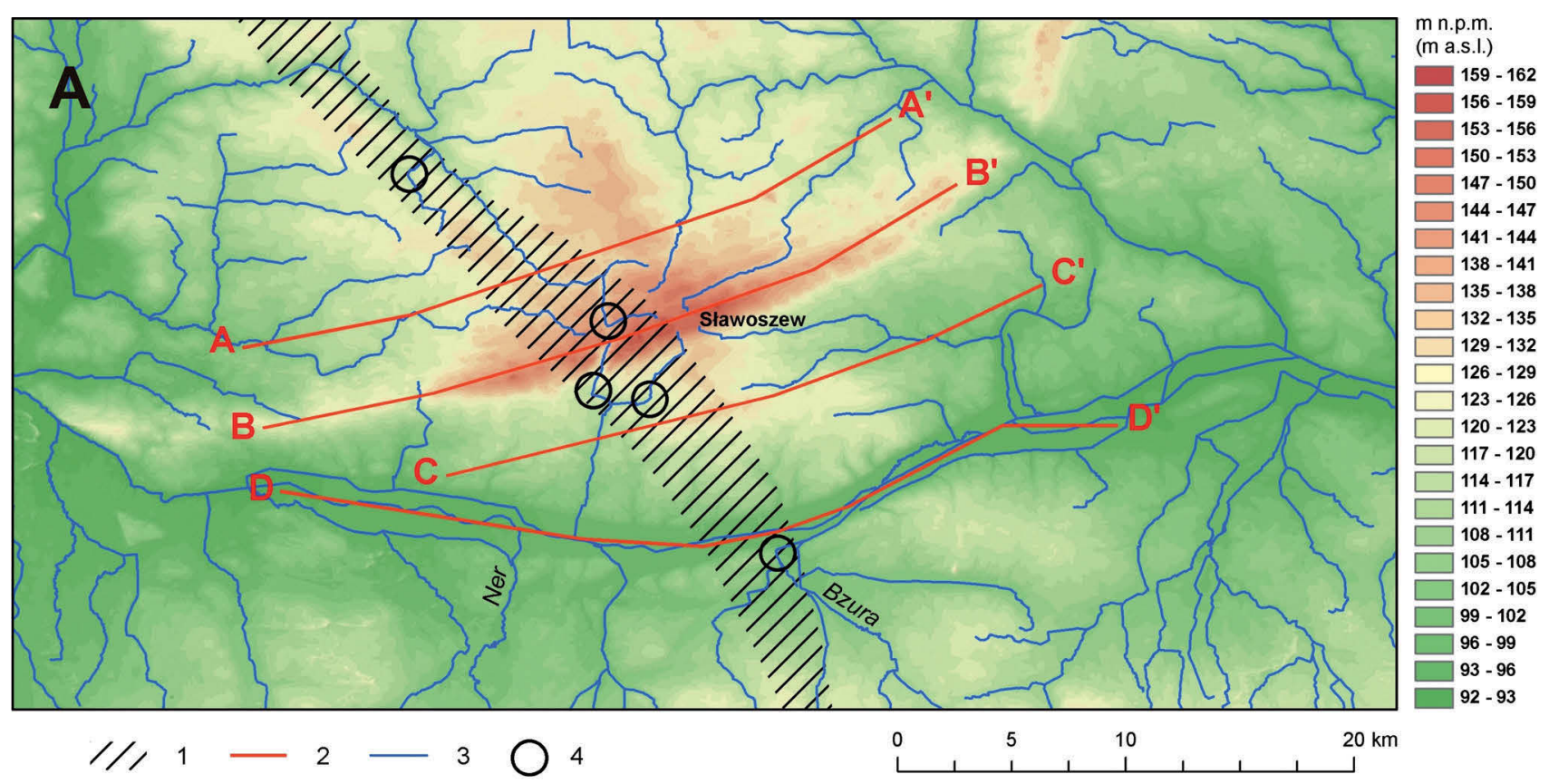

\section{B}

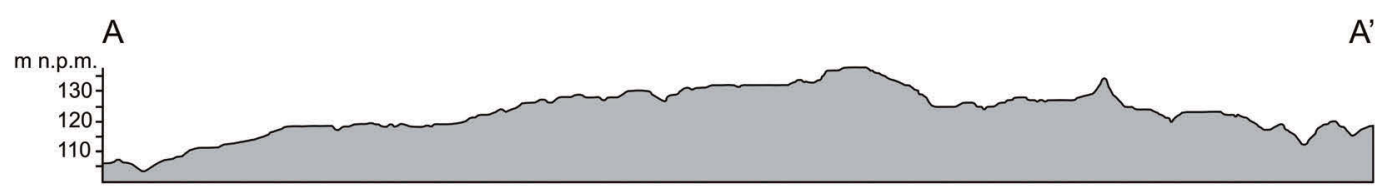

B

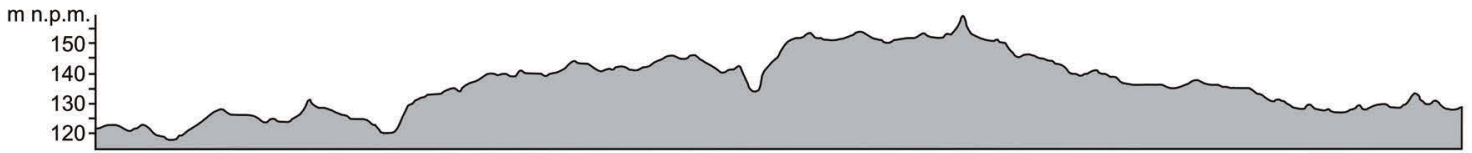

C

$C^{\prime}$

m n.p.m

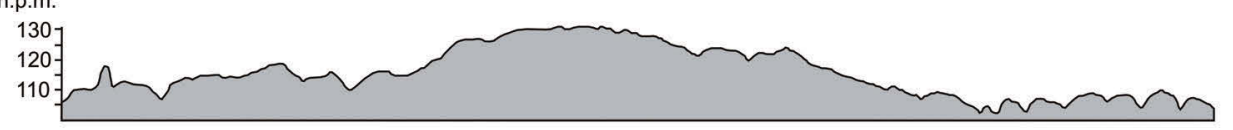

D

Ryc. 6. Numeryczny model terenu (A) i profile hipsometryczne (B) moreny kutnowskiej i wschodniego odcinka pradoliny warszawsko-berlińskiej: 1 - przebieg antykliny solnej Izbica-Łęczyca (za Dadlez i in. 1998); 2 - linie przebiegu profili hipsometrycznych z części B ryciny, 3 - cieki wodne, 4 - przykładowe miejsca nagłych zmian przebiegu cieków wodnych; (B-B') - profil przez morenę kutnowską, (A-A') - profil przez zaplecze wysoczyzny morenowej, (C-C') - profil przez przedpole wysoczyzny morenowej, (D-D') - profil przez dno wschodniego odcinka pradoliny warszawsko-berlińskiej

Fig. 6. Digital terrain model (A) and hypsometric profiles (B) of the Kutno moraines and eastern section of the Warsaw-Berlin pradolina: 1 - course of the Izbica-Łęczyca salt anticline (after Dadlez et al., 1998); 2 - course of the hypsometric profiles of the part B of the figure; 3 - watercourses, 4 - examples of places of sudden changes in course of watercourses; (B-B') -profile across the Kutno moraine, $\left(\mathrm{A}-\mathrm{A}^{\prime}\right)$ - profile across hinterland of the moraine plateau, $\left(\mathrm{C}-\mathrm{C}^{\prime}\right)$ profile across foreland of the moraine plateau as well as (D-D') - profile across the bottom of the eastern section of the Warsaw-Berlin pradolina 
potwierdza budowa geologiczna podłoża współczesnej doliny Bachorzy uformowanej w czasie recesji ostatniego lądolodu. Dolina ta nawiązuje w swym przebiegu do starszej, znacznie szerszej formy dolinnej, którą prawdopodobnie odpływały wody z zastoiska warszawskiego i dalej poprzez dolinę istniejącą na linii współczesnych rynien subglacjalnych, tj. Gopła oraz Jezior Ślesińskiego i Mikorzyńskiego (Molewski 1999, 2007), do pradoliny warszawsko-berlińskiej z pominięciem jej wschodniego odcinka. Wysokość stropu osadów kopalnej doliny Bachorzy, uwzględniając jego postglacjalne wypiętrzenie, wskazuje, że odpływ wód przez dolinę z zastoiska warszawskiego mógł odbywać się jeszcze, gdy poziom wód zastoiska przekroczył 80 m n.p.m.

Przeprowadzona estymacja czasu wypełnienia zastoiska warszawskiego wodami ekstra- i proglacjalnymi sugeruje, że mimo skrócenia czasu funkcjonowania zastoiska z 2000 lat do maksymalnie 300 lat, okres ten był zbyt długi, aby zastoisko mogło istnieć bez ,kanału ulgi”. Zatem musiał istnieć z niego odpływ przed ponownym udrożnieniem przepływu m.in. przez reprodukowaną dolinę marginalną Bachorzy. Jedyną drogą odpływu wód $\mathrm{z}$ zastoiska warszawskiego w czasie maksimum ostatniego zlodowacenia pozostaje więc pradolina warszawsko-berlińska. Analiza potencjalnych wznoszących ruchów skorupy ziemskiej na obszarze obejmującym morenę kutnowską i pradolinę warszawsko-berlińską w okolicy Łęczycy sugeruje, że od schyłku ostatniego zlodowacenia teren ten mógł podnieść się o 10-15 m. W konsekwencji obniżenie dna pradoliny o kilkanaście metrów pod Łęczycą umożliwiałoby odpływ wód z zastoiska warszawskiego nie tylko w poziomie 102 m, ale nawet około $84 \mathrm{~m}$ n.p.m.

\section{Literatura}

Baraniecka M.D., Konecka-Betley K., 1987. Fluvial sediments of the Vistulian and Holocene in the Warsaw Basin. W: L. Starkel (red.), Evolution of the Vistula river valley during the last 15000 years, part II. Geographical Studies IGiPZ PAN Special Issue 4: 151-170.

Brzeziński M., 2003, Objaśnienia do Szczegółowej mapy geologicznej Polski 1:50 000. Arkusz Brześć Kujawski (441). NAG, PIG-PIB, Warszawa.

Dadlez R., Iwanow A., Leszczyński K., Marek S., 1998. Mapa tektoniczna kompleksu cechsztyńsko-mezozoicznego 1:500 000. W: R. Dadlez (red.), Mapa tektoniczna kompleksu cechsztyńsko-mezozoicznego na Niżu Polskim 1:500 000. PIG, Wyd. Kart. PAE SA, Warszawa.

Galon R., 1929. Kujawy „Białe” i „Czarne”. Badania Geograficzne nad Polską Północno-Zachodnią 4-5: 48-76.

Ge H., Jackson M.P.A., Vendeville B.C., 1997. Kinematics and dynamics of salt tectonics driven by progradation. AAPG Bulletin 81(3): $398-423$.

Holbrook J., Schumm S.A., 1999. Geomorphic and sedimentary response of rivers to tectonic deformation: a brief review and critique of a tool for recognizing subtle epeirogenic deformation in modern and ancient settings. Tectonophysics 305: 287-306.

Jewtuchowicz S., 1967. Geneza pradoliny warszawsko-berlińskiej między Nerem i Moszczenicą. Prace Geograficzne IG PAN 62.
Jeziorski J., 1990. Objaśnienia do Szczegółowej mapy geologicznej Polski 1:50 000. Arkusz Bobrowniki (402). PIG, Warszawa.

Kondracki J., 1998. Geografia regionalna Polski. Wyd. Nauk. PWN, Warszawa.

Lencewicz S., 1927. Dyluwium i morfologia środkowego Powiśla. Prace PIG 2(2).

Mojski J.E., 2005. Ziemie polskie w czwartorzędzie. Zarys morfogenezy. PIG, Warszawa.

Molewski P., 1999. Rynna Gopła - problem jej genezy i roli w odpływie wód roztopowych podczas zlodowacenia vistuliańskiego. Studia Societatis Scientiarum Torunensis, Geographia et Geologia 10(6).

Molewski P., 2007. Neotektoniczne i glacidynamiczne uwarunkowania wykształcenia plejstocenu Wysoczyzny Kujawskiej. Wyd. Nauk. UMK, Toruń.

Molewski P., 2012a. Objaśnienia do Szczegółowej mapy geologicznej Polski 1:50 000. Arkusz Inowrocław (400). PIG-PIB, Warszawa.

Molewski P., 2012b. Odpływ wód z zastoiska warszawskiego w czasie stadiału głównego zlodowacenia wisły - nowe aspekty starego problemu. W: Korelacja osadów plejstocenu na pograniczu polsko-niemieckim w Dolinie Dolnej Odry. XIX Konferencja - Stratygrafia Plejstocenu Polski, Cedynia, PIG-PIB, Warszawa: 81-84.

Molewski P., 2013. Szczegółowa mapa geologiczna Polski 1:50 000. Arkusz Inowrocław (400). PIG-PIB, Warszawa.

Niewiarowski W., 1983a. Postglacjalne ruchy skorupy ziemskiej na Pojezierzu Kujawskim w świetle badań geomorfologicznych. Przegląd Geograficzny 55(1): 13-29.

Niewiarowski W., 1983b. The origin and development of marginal channels and valleys: a case study the Kuyavian Lake District. W: D.J. Briggs, R.S. Waters (red.), Studies in Quaternary Geomorphology. Intern. Symp. Ser., Cambridge University Press: 97-108.

Sobczak A., Sydow S., 2009. Objaśnienia do Szczegółowej mapy geologicznej Polski 1:50 000. Arkusz Przysiek (401). NAG, PIG-PIB, Warszawa.

Schumm S.A., Dumont J.F., Holbrook J.M., 2000. Active tectonics and alluvial rivers. Cambridge University Press.

Wilkosz P., 2008. Wpływ zlodowaceń plejstoceńskich na aktywność wysadów solnych. XIII Międzynarodowe Sympozjum Quo Vadis Sal, Demanovska Dolina, Słowacja: 31-32.

Wiśniewski E., 1974. Dolina Bachorzy - problem jej genezy i znaczenia w okresie wczesnośredniowiecznym. Przegląd Geograficzny 46(2): 263-279.

Wiśniewski E., 1976. Rozwój geomorfologiczny doliny Wisły pomiędzy Kotliną Płocką a Kotliną Toruńską. Prace Geograficzne IGiPZ PAN 119.

Wiśniewski E., 1990. Evolution of the Vistula River Valley during the last 15000 years. Part III. Geogr. Stud., Spec. Issue 5: 102-110, 146-153.

Wiśniewski E., 2003. The problem of outflow from the ice-dammed lake in the Warsaw Basin during the Leszno Phase. Prace Geograficzne IGiPZ PAN 189: 123-142.

Wiśniewski E., 2005. Problem drogi odpływu wód z jeziora zaporowego w Kotlinie Warszawskiej podczas fazy leszczyńskiej. Słupskie Prace Geograficzne 2: 131-145.

Wiśniewski E., Andrzejewski L. 1994. The problem of the Warsaw icedammed lake drainage through the Warsaw-Berlin Pradolina at the last ice-sheet maximum. Zeitschrift für Geomorphologie N.F., Suppl.-Bd. 95: 141-149.

Wysota W., Molewski P., 2007. Ostatni lądolód skandynawski w lobie Wisły - kontrowersje i nowe spojrzenie. W: P. Molewski, W. Wysota, P. Weckwerth (red.), Plejstocen Kujaw i dynamika lobu Wisły w czasie ostatniego zlodowacenia. XIV Konferencja - Stratygrafia Plejstocenu Polski, Ciechocinek. Wyd. PIG, Warszawa: 13-21.

Wysota W., Molewski P., 2011. Chronologia i zasięgi nasunięć lądolodu na obszarze lobu Wisły podczas stadiału głównego ostatniego zlodowacenia. Przegląd Geologiczny 59(3): 214-225.

Wysota W., Molewski P., Sokołowski R.J., 2009. Record of the Vistula Ice Lobe advances in the Late Weichselian glacial sequence in north-central Poland. Quaternary International 207, Special Issue: 26-41. 